\title{
In Vitro Construction and Characterization of the Bacteriophage P4 Derivative, P4 sid71 cosP2, Containing the Bacteriophage P2 cos Region
}

\author{
Kyoung-Jin Kim \\ Department of Biomedical Sciences, College of Health Sciences, Sun Moon University, Asan 336-708, Republic of Korea
}

\section{박테리오파지 P2의 $\cos$ 지역을 함유하는 박테리오파지 P4 유도체인 P4 sid71 cosP2의 In vitro 조성과 정성 연구}

\author{
김경진 \\ 선문대학교 건강보건대학 의생명과학과 \\ (Received February 13, 2013 / Accepted March 8, 2013)
}

\begin{abstract}
Bacteriophage P2 sir mutants are inefficient helpers for their satellite bacteriophage P4. The term, "P2 sir-associated helper inefficiency" has been used to define this phenomenon and it has been suggested that the DNA sequence difference between the cos region of $\mathrm{P} 2$ and that of $\mathrm{P} 4$ is responsible. To test this hypothesis, $\mathrm{P} 4$ derivative phage, $\mathrm{P} 4$ sid71 cosP2, containing the cos region of $\mathrm{P} 2$ and sid71 allele was constructed through several in vitro DNA manipulation steps. Its burst size was determined using a one-step growth experiment. The results showed that the substitution of the cos region of $\mathrm{P} 2$ for the cos region of $\mathrm{P} 4$ in $\mathrm{P} 4$ sid71 cosP2 overcame "P2 sir-associated helper inefficiency". $\mathrm{P} 4$ sid 71 cosP2 stock phages prepared with $\mathrm{P} 2$ wild type helper and $\mathrm{P} 2$ sir helper were analyzed using a $\mathrm{CsCl}$ buoyant equilibrium density gradient experiment. The results revealed that the phage particles containing three copies of the P4 genome were the predominant particles in both cases.
\end{abstract}

Keywords: Escherichia coli, bacteriophage P2-P4, cos region, packaging, P2 sir

Bacteriophage $\mathrm{P} 4$ is a satellite phage of the coliphage P2. It has no genes for virion synthesis and can be maintained as a plasmid in the absence of helper phage P2. However, bacteriophage $\mathrm{P} 4$ requires bacteriophage $\mathrm{P} 2$ as a helper phage for its lytic growth (Bertani and Six, 1988). The genome size of $\mathrm{P} 2$ is $33.5 \mathrm{~kb}$ long and the genome size of $\mathrm{P} 4,11.6 \mathrm{~kb}$, is one-third of that of $\mathrm{P} 2$. The sid (size determination) gene of $\mathrm{P} 4$ was isolated due to its ability to enforce P2 to assemble small head (Shore et al., 1978). The gpSid of P4, which forms an external scaffold around the P4-size prohead, enables P2 to assemble a P4-size head suitable for packaging the P4 genome (Marrvik et al., 1995; Dearborn et al., 2012). P4 sid mutants fail to assemble P4-size head. Two or three copies of the P4 sid genome are packaged into P2-size heads (Shore et al., 1978; Song and Kim, 2006). P2 mutants, which can assemble large P2-size heads in the presence of $\mathrm{P} 4$, have been isolated and called $\mathrm{P} 2$ sir (sid

*For correspondence. E-mail: kjkim@sunmoon.ac.kr; Tel.: +82-41-5302273; Fax: +82-41-530-2939 responsiveness) (Six et al., 1991). These sir mutations were identified in the $N$ gene of $\mathrm{P} 2$, which encodes the capsid protein of P2. When P2 sir acted as a helper for P4, only P2-size heads were assembled and two or three copies of the $\mathrm{P} 4$ genome were packaged into those P2-size heads (Six et al., 1991).

When P4 sid infects the P2 sir lysogen host, we would expect vigorous production of $\mathrm{P} 2$-size head particles packaged with two or three copies of the P4 genome. But the actual production of progeny particles was inhibited, in this case (Six et al., 1991; Kim et al., 1998). This tells us that P2 sir cannot efficiently act as a helper phage for P4. The term, "P2 sir-associated helper inefficiency" has been coined to define this phenomenon (Kim, 2003).

Factors affecting P2 sir-associated helper inefficiency have been investigated to obtain information concerning the cos-cleavage and packaging mechanisms of the P2-P4 bacteriophage system. P4 ost 1 and $\mathrm{P} 4$ ost 2 were isolated and studied as suppressor mutants of P2 sir3, which showed a strong Sir phenotype (Kim et al., 1998; Kim, 2003). From the 
identification and characterization of these suppressor mutants, it was suggested that a key factor was the genome size of the packaged DNA in the $\mathrm{P} 2_{\text {sir }}$-size head. As P4 ost 1 and P4 ost 2 constitute an in vivo recombinant of a P4 multimer having a deletion, their genome size could not be compared with that of P4 packaged into a P2-size head, usually two copies of the P4 genome $(23.2 \mathrm{~kb})$ or three copies of the $\mathrm{P} 4$ genome $(34.8 \mathrm{~kb})$. Actually, the genome sizes of P4 ost 1 and $\mathrm{P} 4$ ost 2 are $26.6 \mathrm{~kb}$ and $28.8 \mathrm{~kb}$, respectively (Kim et al., 1998; Kim, 2003). Therefore, P4 ost 1 and $\mathrm{P} 4$ ost 2 represent special cases for overcoming P2 sir-associated helper inefficiency.

Despite the P2 sir-associated helper inefficiency associated with P2 sir mutants, most P2 sir mutants, except P2 sir3, can apparently package their own DNA quite well (Six et al., 1991). This implies that the $\mathrm{P} 2_{\text {sir }}$-size head interacts differently with the P4 and P2 genomes during cos-cleavage and packaging. Ziermann and Calendar (1990) defined the cos region of P2 and P4 as a DNA sequence around the cos-site, which is necessary for cos-cleavage and packaging, by transduction experiments. The cos regions of P2 and P4 begin at about $120 \mathrm{bp}$ upstream of the first nucleotide of the $\cos$-site and end at the last nucleotide of the $\cos$-site. They are composed of the $\cos$-site or $\cos$ nicking site $(\cos N)$ and the binding sites for the terminase, possibly the prohead, and other proteins involved in packaging $(\cos B)$. Although the $19 \mathrm{bp}$-long cos-site of $\mathrm{P} 4$ is identical to that of $\mathrm{P} 2$, the DNA sequence surrounding the cos-site of $\mathrm{P} 4$ is not homologous to $\mathrm{P} 2$ (Ziermann and Calendar, 1990). The alignment of the DNA sequences including the cos regions of bacteriophages P2 and P4 is shown in Fig. 1. Conserved sequences appear from -143 to $-137,-113$ to $-107,-102$ to $-97,-29$ to -13 and -9 to -2 . Conceivably, some of the sequence intervals for which P4 DNA differ from P2 DNA may be important for interaction with the $\mathrm{P} 2$ sir -size head and the low efficiency of $\mathrm{P} 2$ sir mutants as helpers for P4. It is assumed that the $\cos B$ sites of $\mathrm{P} 4$ differing from those of P2 may cause P2 sir-associated helper inefficiency. In the present study, this assumption was examined with the $\mathrm{P} 4$ (or sid71) derivative containing the $\cos$ region of $\mathrm{P} 2$ instead of the $\cos$ region of $\mathrm{P} 4$.

To obtain the DNA fragment containing the cos region of $\mathrm{P} 2$, the phage DNA of P2 was first isolated according to a previous method (Lindqvist, 1971). Isolated linear P2 phage DNA was circularized with a mild ligase treatment. A PCR reaction was performed with this circularized P2 phage DNA as a template using specific primers (P2BSP primer: 5' -GGTGGTTCCGGATACGAAACGCTTT-3' primer and P2XHO

\section{P2: -174 ATTTGTATGC AATGAGTTCA TACGAAACGC TTTTTTACAT P4: -174 GTCAGTGTAA AATTCCCCGA AAATCCGCCC GTTTTTACTG BspE I site}

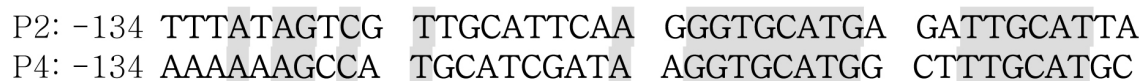

P4: -94 AGGGAAACTG TGATATGGCT TGCTTTTTGA CTGGAAATAC P2: -94 GTTTTCCTGC CTCATTTTCT GCAAACCGCG CCATTCCCGG

P2: -54 TGATGGCTCA TTAGTTTTAT TAAGGTGCAT TAAAACCGCC P4: -54 CGCGGTCTGA GCGTGTCAGT GCAACTGCAT TAAAACCGCC
P2: - 14 CCGTGAAGCG GGCGGGCGAG GCGGGGAAAG CACTGCGCGC P4: - 14 CCGCAAAGCG GGCGGGCGAG GCGGGGAAAG CACCGCGCGC

$+1 \quad \cos N$ site

\section{P2: 27 TGACGGTGGT GCTGATTGTA TTTTTTCAGC GTCTCAGCGC P4: 27 AAACCGACAA GTTAGTTAAT TATTTGTGTA GTCAAAGTGC}

Fig. 1. Alignment of the cos regions of bacteriophages P2 and P4. Position number 1 indicates the $\mathrm{G}$ at the beginning of the left cohesive end found for the DNA of linearized phages. In the P2 and P4 sequences, the shading regions indicate the same nucleotides appearing in P2 and P4 sequences. The underlined $B s p \mathrm{EI}$ and $\mathrm{XhoI}$ sites indicate the nucleotides where the restriction enzyme recognition sites were introduced by in vitro mutagenesis in this study. 
primer: 5'-TGAAGGCACTCGAGGCACTTTG-3' where the underlined sequences indicate the $B s p \mathrm{EI}$ and $\mathrm{XhoI}$ restriction endonuclease recognition sequences, respectively). The resulting 220 bp-long amplified fragment was digested with both enzymes. Finally a "P2 cos region module," which has a $B s p$ EI site at one end and an $\mathrm{XhoI}$ site at the other end, was obtained.

P4 genomic DNA was isolated as a plasmid from a nonlysogenic E. coli C1a strain harboring P4 (Lin, 1984). The $1.2 \mathrm{~kb}$ BamHI-EcoRI portion of the P4 DNA containing the cos region of $\mathrm{P} 4$ was ligated with the BamHI/EcoRI digested pUC19 (NEB, USA) to construct a pKJK49 plasmid. The restriction endonuclease recognition sites, BspEI and XhoI, were introduced at $-162 \mathrm{bp}$ and at $+57 \mathrm{bp}$ of $\mathrm{P} 4$ sequences in pKJK49 by in vitro mutagenesis with the QuickChange ${ }^{\mathrm{TM}}$ Mutagenesis Kit (Stratagene, USA) for the P2 cos region module exchange. For the introduction of the BspEI site in pKJK49, a PCR reaction was performed with pKJK49 as a template using P4BSE (5'-AGTGTAAAATTCTCCGGAAAT CCGCCCGT-3') and P4BSER (5'-ACGGGCGGATTTCCGG AGAATTTTACACT-3') primers. According to the procedure in the QuickChange ${ }^{\mathrm{TM}}$ Mutagenesis Kit, the amplified fragments were digested with $D p n$ I to remove the template DNA. E. coli JM105 was transformed with that DNA to get a clone-harboring derivative pKJK49 with a BspEI site. For the introduction of an $X h o I$ site, a PCR reaction was performed with the derivative pKJK49 with the BspEI site as a template using P4XHO (5'-CA AAGTGCCTCGAGTGCCTTCA-3') and P4XHOR (5'-TGAA GGCACTCGAGGCACTTTG-3') primers. Through DpnI digestion and transformation, a pKJK49 plasmid having BspEI and XhoI recognition sites was constructed. The introduction of $B s p E I$ and $X h o I$ recognition sites was identified by DNA sequencing.

The cos region replacement was performed between the BspEI/XhoI digested pKJK49 derivative and the $\mathrm{P} 2$ cos region module. The resulting plasmid was called pKJK76. The swapping of the $\cos$ region of $\mathrm{P} 4$ for the $\cos$ region of $\mathrm{P} 2$ in pKJK76 was confirmed by DNA sequencing.

P4 (or sid71) plasmid DNA was digested with two single cutters, SalI (at nucleotide number 3,043 of the P4 DNA sequence) and MluI (at nucleotide number 8,624 of the P4 DNA sequence), and ligated with SalI/MluI digested pGEM5Z (Promega, USA) to get two kinds of recombinant plasmids covering the whole $\mathrm{P} 4$ genome. The resulting two plasmids were called pKJK77 (or pKJK78 for the sid71 allele) and pKJK100 (Fig. 2). The pKJK77(or pKJK78) had portions of P4 DNA starting at nucleotide number 8,624 of the P4 DNA sequence extending past $\cos$ and ending at nucleotide number 3,043 of the P4 DNA sequence. The pKJK77 (or pKJK78) insert contained late genes, such as sid (sid71 allele in
pKJK78), delta and psu, and the cos region. The pKJK100 insert had the remaining portion of the P4 DNA starting at nucleotide number 3,043 of the P4 DNA sequence and ending at nucleotide number 8,624 of the P4 DNA sequence.

An approximate $1.2 \mathrm{~kb}$-long BamHI-EcoRI fragment containing the cos region of $\mathrm{P} 2$ in $\mathrm{pKJK} 76$ was taken and replaced with the BamHI-EcoRI fragment of pKJK77 (or pKJK78 for the sid71 allele). The resulting plasmid was called pKJK79 (or pKJK80 for the sid71 allele). The pKJK79 (or pKJK80) insert is consisted of nearly half of the $\mathrm{P} 4$ genome and contains the cos region of $\mathrm{P} 2$ instead of the cos region of $\mathrm{P} 4$. The insert was taken by SalI/MluI double digestion of pKJK79 (or pKJK80) and ligated with the SalI/MluI double digested pKJK100 to make up the remaining portion of the $\mathrm{P} 4$ genome (see Fig. 2 for the construction procedure). The competent cells of the P2 lysogenic strain, E. coli C295, was transformed with the ligation mixture and poured onto an LB-agar plate with a fresh overnight culture of E. coli C295. The plaques appearing on that plate after overnight incubation were chosen as transfectant $\mathrm{P} 4$ derivatives containing the $\cos$ region of $\mathrm{P} 2$. Only the correctly ligated $\mathrm{P} 4$ portions made up the $\mathrm{P} 4$ genome having the cos region of $\mathrm{P} 2$ and multiplied as a $\mathrm{P} 4$ phage in the

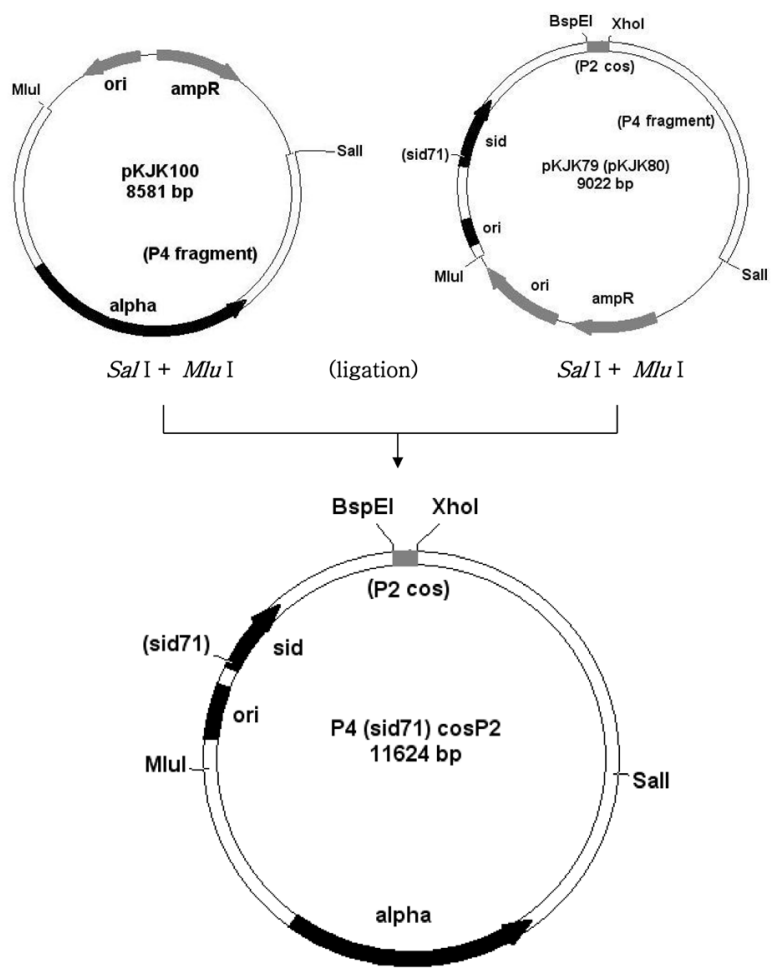

Fig. 2. Construction of $\mathrm{P} 2 \operatorname{sid} 71 \cos \mathrm{P} 2$. The restriction enzyme cutting sites used in this construction are shown. Some genes, the exchanged $\mathrm{P} 2$ cos region, and ori of $\mathrm{P} 4$ are also shown. The thick white box indicates the P4 DNA portion and the thin line indicates the plasmid DNA portion. 
102 Kyoung-Jin Kim

Table 1. Burst size of $\mathrm{P} 4$ and derivatives

\begin{tabular}{lcc}
\hline \multirow{2}{*}{ Phage } & \multicolumn{2}{c}{ Burst size with C1a lysogenic for ${ }^{\mathrm{a}}$} \\
\cline { 2 - 3 } & $\mathrm{P} 2 \operatorname{sir}+$ & $\mathrm{P} 2 \operatorname{sir} 2$ \\
\hline $\mathrm{P} 4$ & $121.5 \pm 5.8$ & $0.8 \pm 0.1$ \\
$\mathrm{P} 4 \cos \mathrm{P} 2$ & $89.4 \pm 6.2$ & $0.8 \pm 0.1$ \\
$\mathrm{P} 4 \operatorname{sid} 71$ & $36.9 \pm 9.6$ & $4.4 \pm 1.0$ \\
$\mathrm{P} 4 \operatorname{sid} 71 \cos \mathrm{P} 2$ & $46.2 \pm 10.9$ & $51.7 \pm 8.8$ \\
\hline${ }^{\mathrm{a}}$ All burst size data is the Mean \pm SD of more than three independent \\
experiments
\end{tabular}

presence of helper P2 prophage in the E. coli C295 strain and formed a plaque. The concentrated phage stocks were made from those transfectants, according to Kim and Song (2006). The substitution of the $\mathrm{P} 2 \cos$ region for the $\mathrm{P} 4 \cos$ region and the presence of the sid71 allele of the transfectant phages were identified by DNA sequencing. Finally, the cos region of P2 containing $\mathrm{P} 4$ derivative phages were called $\mathrm{P} 4 \cos \mathrm{P} 2$ and $\mathrm{P} 4$ sid71 $\cos \mathrm{P} 2$ for the one having a sid71 allele.

At first, the burst sizes of $\mathrm{P} 2 \cos$ containing $\mathrm{P} 4$ derivatives, $\mathrm{P} 4 \cos \mathrm{P} 2$ and $\mathrm{P} 4 \operatorname{sid} 71 \cos \mathrm{P} 2$, were determined with wild type P2 lysogen (C295) and P2 sir2 lysogen (C2142) hosts. To determine the burst size, one-step growth experiments were done according to the method previous used by Kim and Song (2006). All strains used in these experiments were derived from C1a, a type strain of E. coli C (Sasaki and Bertani, 1965). As shown in Table 1, the burst size for $\mathrm{P} 4 \cos \mathrm{P} 2$ with wild type $\mathrm{P} 2$ lysogen was smaller than that for the P4 with wild type P2 lysogen. With P2 sir2 lysogen, the burst size for P4 was the same as that for $\mathrm{P} 4 \cos \mathrm{P} 2$. In the case of $\mathrm{P} 4 \operatorname{sid} 71 \cos \mathrm{P} 2$, the burst size with P2 sir2 lysogen was higher than that with the wild type P2 lysogen. Comparing the burst sizes for P4 sid71 (4.4) and P4 sid71 cosP2 (51.7) with P2 sir2 lysogen, there was more than ten times the increment in burst size for $\mathrm{P} 4$ sid71 $\cos \mathrm{P} 2$. For $\mathrm{P} 4 \operatorname{sid} 71$ and $\mathrm{P} 4 \operatorname{sid} 71 \cos \mathrm{P} 2$, the ratio of burst size with $\mathrm{P} 2$ sir2 lysogen to that with P2 lysogen was determined to observe the P2 sir-associated helper efficiency ratio (Table 2). The ratio of $\mathrm{P} 4 \operatorname{sid} 71 \cos \mathrm{P} 2$ (1.12) showed that the substitution of the cos region of $\mathrm{P} 2$ for the cos region of $\mathrm{P} 4$ in $\mathrm{P} 4$ sid71 $\cos \mathrm{P} 2$ overcame $\mathrm{P} 2$ sir-associated helper inefficiency.

It has been known that the prohead plays an important role in cos-cleavage and the packaging reaction in the P2-P4 bacteriophage system (Pruss et al., 1975). As the sir mutations reside on the $N$ gene, there would be some difference between the prohead made of wild type $N$ gene product $(\mathrm{gpN})$ and the prohead made of mutant $N$ gene product $\left(\mathrm{gpN}_{\text {sir }}\right.$ ) (Six et al., 1991). It might be possible that the prohead made of mutant $N$ gene product $\left(\mathrm{gpN}_{\text {sir }}\right)$ prefers the $\cos$ region of $\mathrm{P} 2$ in cos-cleavage and packaging. A relatively high burst size and the $\mathrm{P} 2$ sir-associated helper efficiency ratio of $\mathrm{P} 4 \operatorname{sid} 71 \cos \mathrm{P} 2$ compared to those of $\mathrm{P} 4$ sid71 shown in this study support the
Table 2. The ratio of burst size (B.S.) with P2 sir2 to B.S. with P2

\begin{tabular}{lc}
\hline Phage & B.S. with P2 sir2 lysogen/ B.S. with P2 lysogen \\
\hline $\mathrm{P} 4 \operatorname{sid} 71$ & 0.12 \\
$\mathrm{P} 4 \operatorname{sid} 71 \cos \mathrm{P} 2$ & 1.12 \\
\hline
\end{tabular}

notion that the $\cos$ region of $\mathrm{P} 2$ in $\mathrm{P} 4 \operatorname{sid} 71 \cos \mathrm{P} 2$ may interact more efficiently with the prohead made of mutant $N$ gene product $\left(\mathrm{gpN}_{s i r}\right)$ in $\cos$-cleavage and packaging. Therefore, the cos region of $\mathrm{P} 2$ is one of the important factors for $\mathrm{P} 4$ genomes packaged into the P2-size head in overcoming P2 sir-associated helper inefficiency.

The packaging of $\mathrm{P} 2 \operatorname{sid} 71 \cos \mathrm{P} 2$ was examined using the $\mathrm{CsCl}$ buoyant equilibrium density gradient experiment, as described by Nilssen et al. (1996). Portions of phage stocks were mixed with $\mathrm{CsCl}$ solution and the average density adjusted to $1.38 \mathrm{~g} / \mathrm{ml}$. To obtain the density gradient, the mixtures were centrifuged in a Beckman Ultracentrifuge (model LE-80K) at $55,000 \times \mathrm{g}(\mathrm{SW} 41.1 \mathrm{Ti}$ rotor at $21,000 \mathrm{rpm})$ for $60 \mathrm{~h}$ at $4{ }^{\circ} \mathrm{C}$. After centrifugation, the tubes were punctured at the bottom and 28 fractions ( $400 \mu \mathrm{l}$ for each fraction) were collected. The refractory index of each fraction was determined using an Abbe refractometer (Atigo model DR-A1, Japan) and converted to the density of the $\mathrm{CsCl}$ solution. Each fraction was titrated for P4 PFUs (plaque forming units) using C353 as an indicator. The density profile was obtained by plotting the PFUs of each fraction against its density.

Figure 3 shows the profiles for $\mathrm{P} 4 \operatorname{sid} 71$ and $\mathrm{P} 4 \operatorname{sid} 71 \cos \mathrm{P} 2$. In the profile of the $\mathrm{P} 4$ sid71 stock prepared with wild type $\mathrm{P} 2$ lysogen (Fig. 3A), two peaks appeared at the densities corresponding to the $\mathrm{P} 2$-size head packaged with three copies of the P4 genome and to the P2-size head packaged with two copies of the P4 genome, respectively. This profile is identical to that obtained in a previous study by Song and Kim (2006). However, in the case of the $\mathrm{P} 4 \operatorname{sid} 71 \cos \mathrm{P} 2$ stock prepared with wild type P2 lysogen (Fig. 3B), only one peak appeared at the density corresponding to the P2-size head packaged with three copies of the $\mathrm{P} 4$ genome. This difference in density profile may reflects the difference in $\cos$-cleavage and packaging between $\mathrm{P} 4$ sid71 and $\mathrm{P} 4$ sid71 $\cos \mathrm{P} 2$.

The phage stocks of $\mathrm{P} 4 \operatorname{sid} 71$ and $\mathrm{P} 4 \operatorname{sid} 71 \cos \mathrm{P} 2$ prepared with P2 sir2 lysogen (C2142) as a host were examined using the $\mathrm{CsCl}$ buoyant equilibrium density gradient; their density profiles are shown in Figs. 3C and 3D. In the case of P4 sid71 (Fig. 3C), only one peak appeared at the density corresponding to the P2-size head packaged with two copies of the P4 genome. The profile of the $\mathrm{P} 4$ sid71 stock with the $\mathrm{P} 2$ sir2 lysogen host was different from that of the $\mathrm{P} 4$ sid71 stock with the P2 wild type lysogen host (compare Fig. 3A with Fig. 3C). The profile of the $\mathrm{P} 4 \operatorname{sid} 71 \cos \mathrm{P} 2$ stock with the $\mathrm{P} 2 \operatorname{sir} 2$ 
lysogen host (Fig. 3D) showed the same pattern as that obtained with the $\mathrm{P} 4 \operatorname{sid} 71 \cos \mathrm{P} 2$ stock with the $\mathrm{P} 2$ wild type lysogen host (Fig. 3B). In both profiles, only one peak appeared at the density corresponding to the P2-size head packaged with three copies of the P4 genome.

The difference in the packaging status of $\mathrm{P} 4$ sid71 and $\mathrm{P} 4$ sid71 $\cos \mathrm{P} 2$ with $\mathrm{P} 2 \operatorname{sir} 2$ lysogen host may explain why $\mathrm{P} 4$ sid71 $\cos \mathrm{P} 2$ overcomes $\mathrm{P} 2$ sir-associated helper inefficiency. The most plausible hypothesis is as follows: The cos region of $\mathrm{P} 2$ in $\mathrm{P} 4 \operatorname{sid} 71 \cos \mathrm{P} 2$ is a more preferred substrate for $\cos$-cleavage and packaging with the $\mathrm{P} 2_{\text {sir }}$-size prohead-containing complex than the cos-region of $\mathrm{P} 4$ in $\mathrm{P} 4$ sid71. Therefore, the genome of $\mathrm{P} 4 \operatorname{sid} 71 \cos \mathrm{P} 2$ could be $\cos$-cleaved and packaged to the same extent with the P2 wild type or P2 sir lysogens. Consequently, it appears that $\mathrm{P} 2$ sir-associated helper inefficiency is overcome by $\mathrm{P} 4 \operatorname{sid} 71 \cos \mathrm{P} 2$.

In conclusion, the cos region of $\mathrm{P} 2$ containing the $\mathrm{P} 4$ derivative phage, $\mathrm{P} 4 \operatorname{sid} 71 \cos \mathrm{P} 2$, was constructed through several DNA manipulation steps. Burst size determination and the $\mathrm{CsCl}$ buoyant equilibrium density gradient experiment with $\mathrm{P} 4 \operatorname{sid} 71 \cos \mathrm{P} 2$ showed that the $\cos$ region of $\mathrm{P} 2$ in $\mathrm{P} 4 \operatorname{sid} 71$ $\cos \mathrm{P} 2$ could be one of the important factors in overcoming $\mathrm{P} 2$ sir-associated helper inefficiency for a P4 genome packaged into a P2-size head.

\section{적 요}

박테리오파지 P2 sir 변이체는 그것의 위성파지인 박테리오 파지 P4를 위해 비효율적인 도움파지로 알려졌다. 이러한 현상 을 “P2 sir-관련 도움파지 비효율성"이라고 부르고 있으며, P2와 $\mathrm{P} 4$ 의 $\cos$ 지역에서의 DNA 염기배열 순서 차이가 이러한 현상 을 나타나게 한다고 생각되었다. 이를 검증하기 위해, 여러 단계 의 in vitro DNA 조작을 거쳐 $\mathrm{P} 2$ 의 $\cos$ 지역을 함유하는 유도체 $\mathrm{P} 4$ 인 P4 sid71 $\cos \mathrm{P} 2$ 를 조성하였다. 일단계 생장 실험을 통해 그 것의 후손 방출량을 결정하였다. 그 결과는, $\mathrm{P} 4 \operatorname{sid} 71 \cos \mathrm{P} 2$ 에서 $\mathrm{P} 4$ 의 $\cos$ 지역을 $\mathrm{P} 2$ 의 $\cos$ 지역으로 대체한 것이 "P2 sir-관련 도움파지 비효율성"을 극복한 것으로 나타났다. P2 야생형과 P2 $\operatorname{sir}$ 돌연변이형을 도움파지로 삼아 준비한 $\mathrm{P} 4 \operatorname{sid} 71 \cos \mathrm{P} 2$ 파지 농축액들을 $\mathrm{CsCl}$ 부양 균등밀도 편차실험으로 분석하였다. 그 결과, 양 경우 모두 3 개의 P4 유전체를 가진 파지 입자가 우세한 것으로 나타났다.

\section{Acknowledgements}

This work was supported by the Sun Moon University Research Grant of 2010.
(A)

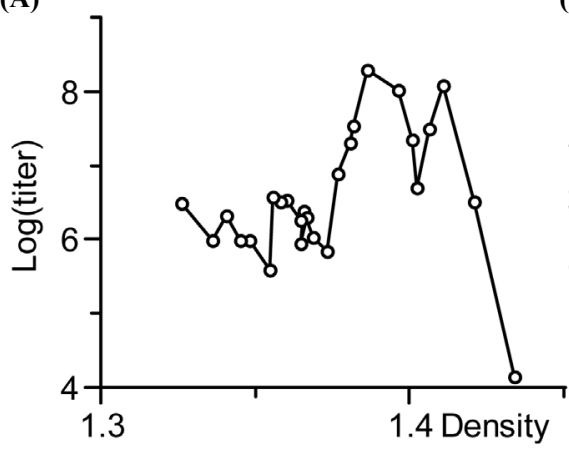

(C)

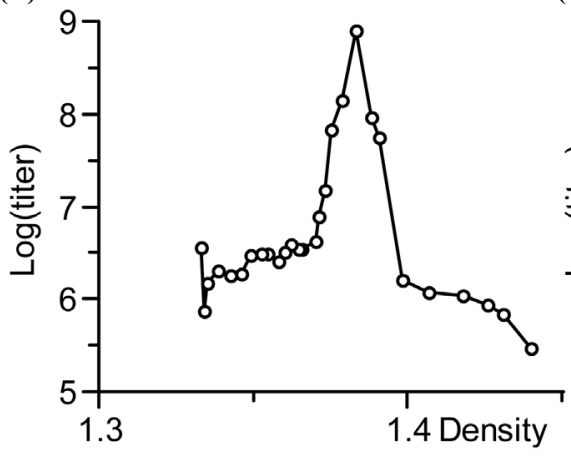

(B)

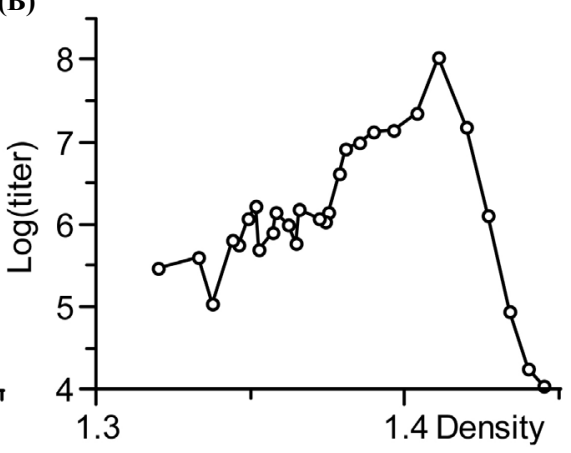

(D)

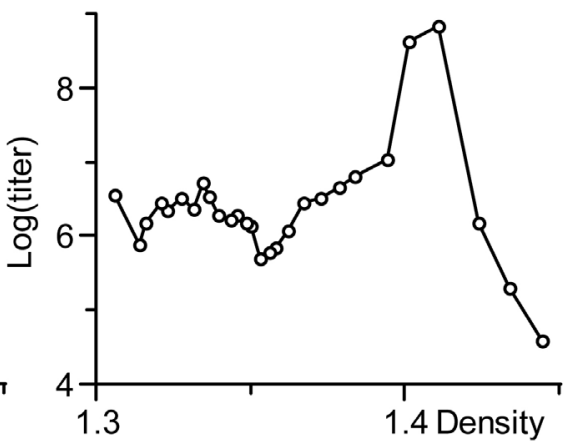

Fig. 3. $\mathrm{CsCl}$ buoyant equilibrium density gradient profiles of $\mathrm{P} 4$ sid71 stock prepared with the w.t. $\mathrm{P} 2$ lysogen host (A); $\mathrm{P} 4$ sid71 cos $\mathrm{P} 2$ stock prepared with the w.t. P2 lysogen host (B); P4 sid71 stock prepared with the P2 sir2 lysogen host (C); and P4 sid71 cosP2 stock prepared with the P2 sir2 lysogen host (D). The ordinates of these profiles show the P4 titer of each fraction expressed in log scale, and the abscissas show the density of each fraction measured with a refractometer. 


\section{References}

Bertani, L.E. and Six, E.W. 1988. The P2-like phages and their parasite, P4, pp. 73-143. In Calendar, R. (eds.), The bacteriophages, vol. 2. Plenumm Press, New York, USA.

Dearborn, A.D., Larurinmaki, P., Chandramouli, P., Rodenburg, C.M., Wang, S., Butcher, S.J., and Dokland, T. 2012. Structure and size determination of bacteriophage $\mathrm{P} 2$ and $\mathrm{P} 4$ procapsids: Function of size responsiveness mutations. J. Struct. Biol. 178, 215-224.

Kim, K-J. 2003. Isolation and identification of the bacteriophage P4 mutant, P4 ost2, suppressing sir mutations of bacteriophage P2. Kor. J. Microbiol. 39, 277-282.

Kim, K.J. and Song, J. 2006. Isolation and chracterization of the smallest bacteriophage P4 derives packaged into P4-size head in bacteriophage P2-P4 system. J. Microbiol. 44, 530-536.

Kim, K-J., Sunshine, M.G., and Six, E.W. 1998. Characterization and identification of the bacteriophage P4 mutant suppressing sir mutations of bacteriophage P2. J. Microbiol. 36, 262-265.

Lin, C-S. 1984. Nucleotide sequence of the essential region of bacteriophage P4. Nucleic Acids Res. 12, 8667-8684.

Lindqvist, B.H. 1971. Vegetative DNA of temperate coliphage P2. Mol. Gen. Genet. 110, 178-196.
Marvik, O.J., Dokland, T., Hanoa, R.N., Jacobse, E., Larson, T., and Lindqvist, B.H. 1995. The capsid size determining protein Sid forms an external scaffold on phage $\mathrm{P} 4$ procapsids. J. Mol. Biol. 251, 59-75.

Nilssen, O., Six, E.W., Sunshine, M.G., and Lindqvist, B.H. 1996. Mutational analysis of the bacteriophage $\mathrm{P} 4$ capsid-size-determining gene. Virology 219, 432-442.

Pruss, G.J., Wang, J.C., and Calendar, R. 1975. In vitro packaging of covalently-closed circular monomers of bacteriophage DNA. J. Mol. Biol. 98, 465-478.

Sasaki, I. and Bertani, G. 1965. Growth abnormalities in Hfr derivatives of Escherichia coli strain C. J. Gen. Microbiol. 40, 365-376.

Shore, D., Deho, G., Tsipis, J., and Goldstein, R. 1978. Determination of capsid size by satellite bacteriophage P4. Proc. Natl. Acad. Sci. USA 75, 400-404.

Six, E.W., Sunshine, M.G., Williams, J., Haggard-Ljungquist, E., and Lindqvist, B.H. 1991. Morphoietic switch mutations of bacteriophage P2. Virology 182, 34-46.

Song, J. and Kim, K-J. 2006. Analysis of DNA conformation in the particles of bacteriophage $\mathrm{P} 4$ mutant, $\mathrm{P} 4$ ash8 sid71. Kor. J. Microbiol. 42, 62-66.

Ziermann, R. and Calendar, R. 1990. Characterization of the cos sites of bacteriophages P2 and P4. Gene 96, 9-15. 